\title{
The Ethics of Ethnomusicology in a Cosmopolitan Age
}

\section{Citation}

Shelemay, Kay Kaufman. 2013. "The Ethics of Ethnomusicology in a Cosmopolitan Age". In The Cambridge History of World Music, ed. Philip V. Bohlman, 786-806. Cambridge University Press.

\section{Published Version}

doi:10.1017/cho9781139029476.044

\section{Permanent link}

http://nrs.harvard.edu/urn-3:HUL.InstRepos:16030699

\section{Terms of Use}

This article was downloaded from Harvard University's DASH repository, and is made available under the terms and conditions applicable to Other Posted Material, as set forth at http:// nrs.harvard.edu/urn-3:HUL.InstRepos:dash.current.terms-of-use\#LAA

\section{Share Your Story}

The Harvard community has made this article openly available.

Please share how this access benefits you. Submit a story.

\section{Accessibility}




\section{The Ethics of Ethnomusicology in a Cosmopolitan Age}

\section{Kay Kaufman Shelemay}

This chapter presents a broad discussion of ethical discourses and practices in the study of world music by ethnomusicologists. ${ }^{\text {ii }}$ In recent ethnomusicological literature, the term "cosmopolitan" has been invoked to refer to "cultural formations that are ... always simultaneously local and

translocal.” (Turino 2000, 7). ${ }^{\mathrm{iii}}$ In the present chapter I give attention to ethical issues surrounding the study of music in an increasingly cosmopolitan age, one in which both people and the music they transmit are simultaneously local and translocal. Ethnomusicological engagement with musics in a cosmopolitan age has transposed longstanding ethical issues into increasingly complex contexts as well as raised new considerations altogether.

Philosopher K. Anthony Appiah has proposed that two moral strands intertwine in the notion of cosmopolitanism:

One is the idea that we have obligations to others, obligations that stretch beyond those to whom we are related by the ties of kith and kind, or even the more formal ties of a shared citizenship. The other is that we take seriously the value not just of human life but of particular human lives, which means taking an interest in the practices and beliefs that lend them significance. People are different, the cosmopolitan knows, and there is much to learn from our differences ... There will be times when these two ideals - universal concern and respect for legitimate difference - clash. There's a sense in which cosmopolitanism is the name not of the solution but of the challenge. (Appiah 2006, xv) 
In the chapter that follows, I wish both to acknowledge the challenge of formulating ethical values in a cosmopolitan world, and to set forth some of the dilemmas that arise as research in cosmopolitan settings proliferates. In the first section I briefly situate ethics in ethnomusicology within a broader framework of philosophical thought and commentary. Next, I trace the history of discourses about ethics within ethnomusicology, addressing issues within the study and pedagogy of world music that either have been or could be the subject of ethical concern. In the third section, I address the growing move in ethnomusicology and sister fields of scholarship into domains of activism and advocacy. In the conclusion, I explore ways in which each individual can articulate ethical codes congruent with his or her research and personal commitments. At the same time, however, I suggest that individual ethics must be anchored by a community of scholars working together to direct attention to positive moral outcomes in ethnographic practices, publications, pedagogy, and activism. At points throughout the chapter I adopt a more reflexive tone, chronicling ways in which my own ethical concerns have both been shaped and transformed over time and within the landscape of different projects.

\section{Ethical frameworks and musical scholarship}

What are ethics and how do they relate to ethnomusicology's study of music traditions around the world? Ethics, incorporated within the field of moral philosophy, are generally defined as the moral principles governing or influencing conduct ('Ethics' 2007). Within the field of philosophy, ethical inquiry extends across three domains moving from the most general and broad examination of the origin and meaning of ethical principles (metaethics), to the more practical moral standards that regulate conduct (normative ethics), to ethics of specific issues (applied ethics). ${ }^{\text {iv }}$ Ethnomusicological discussions of ethics have tended to focus on normative ethics with occasional consideration of the morality attached to specific issues. However, there appear to 
exist shared assumptions about the metaethics of studying world music that implicitly guide ethical philosophy in ethnomusicology: these include, first, that ethics are inflected by a Western notion of human responsibilities of scholars and second, that ethical issues emerge from values of Western culture (Slobin 1992, 330).

Ethical thinking in ethnomusicology is surely shaped by the concept of cultural relativism, which has been a powerful force in the ethnomusicological worldview since at least the mid-twentieth century. I can recall from my own graduate studies in the 1970s the strong relativist credo articulated by my adviser, William P. Malm, who frequently advised his students that "music is not an international language. It consists of a whole series of equally logical but different systems" (Malm 2007). Twentieth-century philosophical relativism, which moved, along with so much of culture theory, through anthropology to other fields (Geertz 2000, 42-67), remains in the twenty-first century a powerful backdrop to cross-cultural musical studies and its ethical values. Moral philosophy in fact incorporates a range of positions on cultural relativism: “The term 'moral relativism' is understood in a variety of ways. Most often it is associated with an empirical thesis that there are deep and widespread moral disagreements and a metaethical thesis that the truth or justification of moral judgments is not absolute, but relative to some group of persons. Sometimes 'moral relativism' is connected with a normative position about how we ought to think about or act towards those with whom we morally disagree, most commonly that we should tolerate them (Gowans, 'Moral Relativism').

There are those who have argued that relativism, especially when combined with the practice of participant observation, has served to distance the ethnographer from ethical issues in the field, impeding one's "ability to write against injustice" (Bourgois 2006, x). Some philosophers today are working to reconcile tenets of relativism with issues of ethics and equality worldwide, acknowledging that desires to respect cultural particularity in ethical and political choices can come into conflict with universalist views (Nussbaum 1995, 5-6). Anthony Appiah argues against a type of relativism that ends discussions by simply articulating different cultural 
positions and thus discourages conversation in a shared world; he suggests that a cosmopolitan approach must ask what system of international rules will respect the more legitimate human interests at stake (Appiah 1996, 126-7). Appiah goes on to propose that cosmopolitan ethics must incorporate "universality plus difference" (ibid., 151).

A summary of the full range of philosophical approaches to ethics is obviously beyond the purview of this chapter, but there are approaches, such as that of Appiah cited above, that grapple with issues very close to ethnomusicological concerns. Appiah's thinking also resonates with Pragmatist philosopher John Dewey's "ethical postulate"; Dewey suggested that there is a reciprocal relation between the realization of each individual's interests and the realization of the interests of all ... Individual and communal self-realization are thus mutually interdependent.” (Welchman 1995, 82). I will return to some of John Dewey's ideas in the conclusion. Given the deep ethnomusicological engagement with cultural relativism and the centrality of ethical concerns to the field, it is useful to explore the history of discourses about ethics in ethnomusicology. This is the subject of part 2.

\section{Discourses about ethics in ethnomusicology and sister disciplines: A brief overview}

Despite the long history of cross-cultural music studies, the subject of ethics entered into the public discussions among music scholars only in the last three decades of the twentieth century. No doubt sparked in part by the lively discourse in anthropological associations, ${ }^{\mathrm{v}}$ public debate about ethical issues in ethnomusicology apparently dates to a panel at the Society for Ethnomusicology's annual meeting in 1972, followed by the establishment of the Society's Committee on Ethics one year later (Slobin 1992, 329-31).

Surely the challenges facing ethnomusicologists in the field and the many questions surrounding ethnographers' roles in these settings sparked much of the early interest in ethical questions. Processes of participant-observation, at their core an intensely personal pursuit of 
'people studying people', ${ }^{\text {vi }}$ provided clear and immediate ethical challenges. But these ethical concerns quickly deepened as, with the emergence of the postcolonial literature and cultural studies, ethnomusicologists began to realize that virtually every aspect of their engagement with the world of music, past and present, required close scrutiny.

While ethnomusicologists have always faced ethical challenges, an acknowledgment of these concerns in print surfaced explicitly only in ethnomusicological publications of the $1980 \mathrm{~s}$. One early discussion is found in the first edition of Bruno Nettl's The Study of Ethnomusicology, which included ethics as one of its twenty-nine issues and concepts (Nettl 1983, 290-300). With the exception of Mark Slobin's overview article on ethical practices (Slobin 1992), there is a paucity of anything extending beyond brief discussions of ethics in the literature. ${ }^{\text {vii }}$

A deep concern with ethical and moral issues, however, is increasingly evident as an unarticulated background issue within many ethnomusicological publications. For instance, although the volume of essays on ethnomusicological fieldwork first published in 1997, Shadows in the Field, did not contain an essay dedicated solely to the subject of ethics, there are substantial discussions of ethical issues in five of its chapters. That volume was also pointedly dedicated to those who have "challenged us to reconsider the fundamental nature of human relationships and understanding in research, fieldwork, scholarship, and life." ${ }^{\text {,iii }}$ It seems clear that ethics have long been among the "shadows" that confront every ethnomusicologist in the course of the ethnographic research process and that these shadows extend well beyond the field into many other domains.

For most ethnomusicologists, ethical issues have been acknowledged to come to the fore within specific situations that arise in the course of the scholarly research process. The Society for Ethnomusicology's formal ethical statement dates from 1998 and is published on the Society's website (Society for Ethnomusicology, 'Position Statement on Ethical Considerations'). This statement sets forth broad expectations for an ethical code while acknowledging that individual values and decisions about courses of action will in many instances differ. 
This carefully calibrated and brief text begins with several general propositions, acknowledges the importance of ethical dialogue and debate, and invites comment and suggestions. The statement reaffirms principles of cultural relativism and acknowledgement of difference, presenting both as vital to ethical behavior among ethnomusicologists and between ethnomusicologists and the peoples with whom they work. The statement then articulates normative principles informing activity in three different domains of ethnomusicological work: field research, publication, and education. The section on the ethics of field research is, not surprisingly given the centrality of ethnographic method to ethnomusicology, the most detailed, addressing individual responsibility for ethical conduct and sensitivity while in the field to matters ranging from informed consent to personal privacy to economic concerns. In general, the SEM statement outlines important areas of ethical concern and serves as a checklist for potential abuses. It does not, however, offer guidance into what may be termed "best practices" for handling a particular ethical dilemma at a given moment. Indeed, the document gently suggests that specific ethical choices must be left to the individual scholar, no doubt for the very good philosophical and pragmatic reasons briefly sketched above.

Other music societies, notably the American Musicological Society in the 1990s, also adopted statements about ethics that are posted on their websites. The AMS "Guidelines for Ethical Conduct," authorized in 1993 and adopted in 1997, is, in contrast to that of the Society for Ethnomusicology, quite detailed (American Musicological Society, 'Guidelines for Ethical Conduct'). The Society for American Music authorized its own detailed "Guidelines for Ethical Conduct" based on the AMS statement in 1998 and prepared in $1999 .^{\text {ix }}$

Professional work in ethnomusicology necessarily raises issues not explicitly addressed in the 2007 "Statement on Ethical Considerations." Scholars are frequently challenged by the ethics associated with the study of musical performance, ranging from the issues surrounding the acquisition of performance skills in the field, to representation of performance in publications, to transmission of performance skills in pedagogy, and to presentation of research associates in 
performance contexts. ${ }^{\mathrm{x}}$ Although a recently published volume of essays addressing the role of performance in ethnomusicological publication and pedagogy does not have an entry for ethics in its index, discussion of the "contested space" of musical performance and the many challenging issues raised throughout the volume clearly engage with a full range of ethical challenges (Solis 2004, 2).

Longstanding issues surrounding ethics of documentation, preservation, and repatriation merit close consideration and should probably receive explicit mention in ethical codes. Although archives have been part of the ethnomusicological heritage for more than a century, concerns have emerged that the materials they house can both canonize certain practices as "authentic," and, under given circumstances, provide "potential tools for political control and the exercise of power" (Klein 2007, 117).

The very process of gathering and archiving data can itself raise important ethical issues. For example, questionnaires administered and archived by the Nordic Museum of Sweden since 1905 about various cultural topics were recently shown to have been manipulated by archivists in many aspects of the collection process (ibid., 123). Troublesome practices included eliciting responses by linking pay to length of answers; alternately encouraging or rejecting certain responses; and then excerpting passages from questionnaires with "some conspicuous deletions and word changes ... in spite of the editor's assurances that the editorial changes have been mainly linguistic" (ibid., 130). Clearly, the processes of archival preservation prominent in ethnomusicological practice deserve ongoing, critical appraisals in order that the issues ranging from collecting practices, to consent (Fjell 2007, 96-113), to access, become subjects of an ongoing critical discourse. I return to some of these issues in the conclusion.

In the realm of interaction between professional and personal domains, there is a growing literature in ethnomusicology about personal relationships in the field (see, e.g., Babiracki 2008, 167-82, and Shelemay 1991), but little in the way of focused discussions about the ethics of these relationships. During my own graduate student years at the University of Michigan, we used to 
comment about the number of us who had met our spouses while in the field and to quip that acquiring a partner was an informal requirement of the research process. While the subject of personal relationships in the field has remained largely within the oral tradition of pedagogy and advising, the range of relationships established and their differing impacts on the research process, as well as on individuals involved, merit serious, public discussion.

If existing guidelines do not set forth specific courses of action, one can surely extract from them an implicit list of ethical "taboos." The most salient taboo seems to be the following: No scholar should neglect to consider carefully her or his behavior in all its aspects and its ethical implications, short and long term, at every stage of her or his professional lives.

Other discussions are not yet on the ethnomusicological map, and some are still highly contentious in other disciplines. These developments may, in the future, raise new questions and provide new insights - of direct relevance to the study of world music, on the levels of metaethics, normative standards, and applied responses. For instance, recent research in evolutionary psychology has proposed a concept of "intuitive ethics," arguing that a subset of ethical sensitivities - such as reciprocity, loyalty, and respect - are innate and intuitive to human beings. At the same time, these intuitive ethics are said to "undergird the moral systems that cultures develop, including their understandings of virtues and character (Haidt and Joseph 2004, 56). The discussion of intuitive ethics may be of interest if it generates a deeper understanding of shared human ethical qualities while respecting cultural differences.

\section{The ethics of world music scholarship multiplied}

The existing code of scholarly ethics in ethnomusicology bears traces of its genesis as a guide for a lone scholar in a bounded cultural locale. It is clear that ethics must be continually rethought in the light of a bewildering array of challenges to ensuring moral behavior in increasingly complex research processes and in new settings. While the Society for Ethnomusicology has taken steps to 
open a more engaged discourse about ethics and to expand the range of subjects that might be discussed in this regard, there is still room for additional thought.

Of the many ethical challenges that confront ethnomusicologists, here I briefly address a complex of issues that relate to ethical issues in plural. By "plural" I mean: 1) The manner in which ethics are multiplied in collaborative research projects, where several individuals or a group must work together, increasing the potential for both good and bad outcomes; 2) the ethical complexity of research pursued in institutional settings or within multiple research sites; and 3) the ways in which the research process can embed or link to other moral concerns not necessarily directly related to music, multiplying the ethical decisions a scholar must make.

Much of the discussion to date about ethnomusicological ethics tacitly assumes that an individual fieldworker can make his or her own ethical decisions on the ground, in the field. This reality, if it ever existed, is fast receding as informal collaboration in the field is more fully acknowledged and as structured, team research becomes more common. Front and center of any team effort are the constant, tricky challenges of deciding on and adhering to ethical standards as a group, whether that team involves collaboration among ethnomusicologists or between an ethnomusicologist and multiple consultants in the field, or both. That a recent book on collaborative ethnography devotes one entire chapter to "Ethics and Moral Responsibility" and a second to "Ethnographic Honesty" underscores this point (Lassiter 2005, 79-116). An entire collaborative research process can be held hostage by a single individual's ethical lapse.

The sheer magnitude of a team project makes it potentially suspect in the way in which an individual's research is often not ethical; trust is harder to establish when a large number of people is involved. In a team project I directed among Syrian Jews in Brooklyn, New York, during which a dozen music graduate students interacted at any one time with as many as twentyfive members of the Syrian Jewish community, the entire project was nearly derailed by a student not participating in our project whose surreptitious research on a non-musical topic came to light in the middle of our carefully negotiated work with the community (Shelemay 1988). It took 
multiple, painful consultations to reassure the community, as well as the apologetic intervention of the student's advisers to resolve what had become a very volatile situation. Although the community with whom we were engaged recognized that no one from our team had been party to the deception, the additional risks of admitting multiple researchers were now clearly evident. As researchers, our team learned that ethical challenges in the field could arise from unsuspected sources, reverberate more loudly amidst a team effort, and jeopardize even the most carefully designed project.

Nowhere are ethical issues more daunting than in institutional research settings. Fieldwork in institutions inevitably requires a series of formal permissions, the use of consent forms, and, often, the signing of privacy agreements well beyond those required for individual or team fieldwork elsewhere, even given the growing presence of institutional research guidelines. When I was invited to spend a summer as an ethnomusicologist at what was then CBS Records in New York City during the mid-1980s, I had to sign confidentiality agreements due to my access to privileged corporate materials and presence at executive meetings. I honored confidentiality and, in the end, was able to write about that experience only indirectly. But this corporate-based ethnographic experience did serve to catalyze my interest in the impact of recording technology and its industry on the history of ethnomusicology (Shelemay 1991b). In the end, the bulk of my observations and increased knowledge about the record industry most directly informed my pedagogy, which is where I transmitted through the oral tradition, with discretion, much of what I had learned. My own brief experience with institutional/corporate fieldwork aside, the entry during the last fifteen to twenty years of so many music researchers into the world of popularmusic research and studies of its global industry, suggests that institutional research may demand its own subset of ethical guidelines in the future.

Multisite research introduces yet more complexities to the ethical equation, multiplying ethical challenges within a single project taking place in different geographical, cultural, national, and/or technologically mediated settings. ${ }^{x i}$ In short, ethical demands in the study of world music 
have increased exponentially, at many moments extending well beyond the boundaries of existing ethical guidelines.

\section{The practice and ethics of an activist ethnomusicology}

The lengthy entry on "Ethnomusicology" in the second edition of The New Grove Dictionary of Music and Musicians notes that the substantial critiques of the culture concept have led to a large literature addressing what may be described as the morality of the ethnographic method; this concern has also sparked interest in ways in which the notion of culture has "often nurtured radical activism by and for the sake of minority, peripheral or disadvantaged groups" (Stokes 2001, 387). Within recent decades, scholars have begun openly to criticize musical scholarship's lack of engagement with music's role in social crisis, as well as assumptions "that its preoccupation as a field with music immunized it from the crises affecting other disciplines within and without the academy" (Bohlman 1993, 414).

If the literature of the last decade tends to address only indirectly the ethics of the ethnomusicological research process, publications have given considerable attention to articulating the responsibility of scholars of world music to issues beyond the conventional boundaries of the research process. One finds ample precedents for and parallels to ethnomusicological activism in fields ranging from anthropology to art.

Unlike ethnomusicologists, anthropologists have moved aggressively not just to consolidate and publish histories of their discourses about ethics (Fluehr-Lobban 2003), but also to generate a new literature that privileges "practical ethical engagement" over theoretical discussions (Meskell and Pels 2005, 1). In anthropology, the personal activism of scholars such as Franz Boas and Bronsilaw Malinowski anticipated by decades the inclusion of a section on "Responsibility to the Public" in the 1971 American Anthropological Association Code of Ethics, 
which affirms the professional obligation of researchers to "contribute their expertise to public policy debates" (Sanford 2006, 3).

Within the world of visual artistic practice and exhibition, the 1990s saw the emergence of relational artistic practices known by a variety of names, including socially engaged art, community-based art, experimental communities, dialogic art, littoral art, participatory, interventionist, research-based, and collaborative arts. A diverse group of artists and the scholars who studied them varied in their objectives and artistic media, but were "linked by a belief in the empowering creativity of collective action and shared ideas" (Bishop 2006, 179). While the discourse in art focuses in part on the nature of the artistic process and its ethical dimensions, individual artists and projects varied in their desire for specific outcomes, with some seeking mainly interchange and dialogue, not necessarily social change (ibid., 180). In the foundational work of Bourriaud on relational aesthetics and its philosophical precedents, however, art is seen to hold the possibility of defining new cultural and political goals (Bourriaud 2006, 161). Art and arts-related initiatives such as the Harvard University-based Cultural Agents seek direct social and political impact from creativity and scholarship "that measurably contribute to the education and development of communities worldwide" ('Cultural Agents').

Political activism has also found its place in public ethnomusicological discourse. In 2005, the Society for Ethnomusicology opened a new space on the SEM website for discussion of very specific matters, situational issues of collective concern and potential action. These issueoriented statements related to ethics and values are termed "Position Statements," which address "issues that affect the field of ethnomusicology, our membership, and the people with whom we work." The statements are accompanied by a brief history of such positions taken by the SEM in the past as well as guidelines for submitting position statements to the SEM Board of Directors. By 2012, the SEM website included six position papers, including the "Statement on Ethical Considerations," but also discussions of Institutional Review Boards, music and torture, and music and fair use." xii While "The Position Statement on Fair Use" clearly addresses major issues 
germane both to the research process and to publications in the field, the "Position Statement on Torture" resonates with growing concerns across music disciplines and beyond about the uses to which music may be put in political contexts related to conflict and war. ${ }^{\text {xiii }}$

Other music societies have posted statements about issues of ethical concern, such as updates on the August 2006 detention of American Musicological Society member Nalini Ghuman on her return from a research visit to the United Kingdom and the subsequent denial of her re-entry into the United States, found on the AMS website (Atkinson, 'From the President'). xiv The Society for American Music subsumes additional ethical issues under "Resolutions Introduced at the SAM Business Meeting, 3 March 2007.” These include a resolution, similar to that of the Society for Ethnomusicology, protesting the use of music as part of psychological torture. The second posting protests suspension of habeas corpus under the Military Commissions Act signed by President Bush in October 2006; it is presented as the subject of a petition circulated to SAM members, but not as an official statement of the Society for American Music as an organization (Society for American Music 2007).

Surely most ethnomusicologists, along with many other music scholars, share convictions that music opens windows on domains extending beyond the performative. Engagement with extra-musical events and issues has a long history in ethnomusicology, particularly among those in the ethnomusicological community who pursue careers outside the university. Usually termed "applied ethnomusicologists," they utilize their knowledge of cross-cultural musical styles within a full range of governmental agencies and cultural institutions. The prominence of applied ethnomusicology from the 1970s onward can be seen from an historical perspective as a continuation of an engaged ethnomusicology similar to that advocated and practiced by Charles Seeger in the 1930s (A. Seeger 2006, 227-8). By the 1990s, there was a deep reappraisal underway among many colleagues in the academy about their responsibilities not just to ensure an ethical scholarship, but to acknowledge their responsibility for its impact outside the ivory tower (Shelemay 1999). 
One notable milestone in the move toward social activism was the appearance of a special issue of the journal Ethnomusicology on "Music and the Public Interest." The articles in this volume hold in common "work whose immediate end is not research and the flow of knowledge inside intellectual communities, but, rather, practical action in the world outside of archives and universities ... In the final analysis, of course, public ethnomusicology does result in knowledge as well as action" (Titon 1992, 315).

As ethnomusicological activism has moved through and beyond the public sector, scholars simultaneously began to turn their attention to new research domains that put them into direct contact with pressing social and political issues. Recent work on Nicaraguan song, for example, focuses on "how cultural workers used music to attempt to confront and supercede the varying legacies that prolonged societal violence left in its wake. ${ }^{\text {,v }}$ The move from close readings of "the relationships between political aspirations and musical performance" (Blacking $1995,198)$, were made in some cases to activity with immediate practical outcomes, such as Gage Averill's turn to music journalism as an outgrowth of his scholarship on music and politics in Haiti (Averill 1997, xix-xxi).

Simultaneously, the contexts in which ethnomusicologists worked and the subjects they could address began to expand, increasing the prospects of social engagement and the growth of an issue-oriented ethnomusicology. New research initiatives include inquiry into medical ethnomusicology, which links grounded ethnography and conventional interpretive scholarship to service-based experimental work and activism in domains such as creative healing arts for both adults and children (Koen 2008; Barz and Cohen 2011). Studies of conflict and violence, such as those carried out by Samuel Araújo and members of the Group Musicultura in Brazil, have both expanded ethnomusicological research interests to domains of urban conflict as well as questioned whether ethnomusicology is doing anything to help disentangle these situations of violence (Araújo et al. 2006). ${ }^{\mathrm{xvi}}$ 
Thus, ethics in ethnomusicology and other music disciplines have for some time extended beyond the conference panel, the printed page, and the classroom into fields of social and political action. Some of the most promising ethnomusicological options for the future are undoubtedly the study of topics that raise, and hopefully, help to resolve, social problems of ethical and moral concern. The domain of what may be termed "musical activism," which is of clear and growing concern to the ethnomusicological community as evidenced in both individual publications and Society for Ethnomusicology initiatives, demands continuous reappraisal and public discussion, not just at the level of individual issues as they arise from time to time, but from broad, metaethical perspectives. Collective interventions by like-minded groups of colleagues on social issues beyond those related to musical life and its study raise many of the same quandaries shadowing the search for best applied ethical practices within the research process itself. Indeed, the "Code of Ethics of the American Anthropological Association" acknowledges this complexity by positioning activism beyond the boundaries of professional ethics altogether and leaving it to individual decision: "Anthropologists may choose to move beyond disseminating research results to a position of advocacy. This is an individual decision, but not an ethical responsibility" (American Anthropological Society 1998).

\section{Ethical options in a cosmopolitan discipline}

How does one bring a discussion of ethics to an ethical conclusion? Surely one cannot present a road map for ethics in the field nor prescribe the course of its discussion. It is clear that ethnomusicologists are now part of a larger process of ethical reappraisal occupying scholars across the disciplines and that this process should and will be ongoing. One can hope that the broader community of music scholars will revisit the tenets of a shared, metaethical philosophy regularly and remain open to critical discussion of the normative ethics that guide professional behavior in its many aspects. The ultimate decisions, however, should remain the domain of the 
individual, who must weigh each ethical or moral challenge in the context of broader propositions and in relation to the particular cultural domain in which the issue has arisen. For pedagogical purposes, it is surely useful to present case studies along with their outcomes in both the oral tradition and in print so that students may be fully aware of the challenges that await them in every aspect of an ethnomusicological career.

I should like to end this chapter with some very personal musing. My own experience suggests that there is only occasionally a single best ethical option, and often there are several possibilities that would have desirable outcomes. One cannot always know which path will insure the most ethical result at the moment of decision.

In my own consideration of professional ethics, the concept and practice of reciprocity has moved front and center. I find quite powerful John Dewey's notion that the relations between individuals are like the relations that hold between members of an ecosystem. "In an ecosystem, no act is without some effect upon the whole ... Individual and communal self-realization are thus mutually interdependent” (Welchman 1995, 82). Dewey’s notion of "symmetric reciprocity," the idea that there is a reciprocal relation between each individual's interests and the realization of the interests of all (ibid.), seems especially apt, and its outcomes, on both professional and personal levels over the course of time, highly desirable. According to Dewey and other American Pragmatist philosophers, ethics must be subject to inquiry and there are no metaphysical guarantees that any of our beliefs will not need revision (Putnam 1995, 200 and 222).

The challenges of reciprocity have come full circle in my own work with Ethiopian immigrants to North America, part of a far-flung Ethiopian diaspora that sprang up in the mid1970s out of the perfect storm of the Ethiopian revolution and a string of natural disasters including drought and famine. ${ }^{\text {xvii }}$ As a dual effort to establish reciprocity and to document otherwise epheremeral individual musical contributions within what is now the second-largest African community living in the United States, ${ }^{\text {xvii }}$ I have organized a collection on the music and 
musicians of the Ethiopian diaspora at the Library of Congress's Archive of Folk Culture. ${ }^{\text {xix }}$ Along with each interview, of which the individual musician received a copy, I deposited each musician's published CDs in the archive so that their music and performance skills are represented in a manner that the musicians themselves controlled. We co-signed a letter of agreement in which each musician gave permission for the deposit of the oral history and detailed how he or she wish to be cited in future scholarship that may be based in part on these materials. In some cases, individuals provided additional documentary materials for deposit beyond their own copyrighted musical recordings, ranging from videotapes, to scrapbooks, to newspaper clippings, to notated chant manuscripts. In these cases, I tried to reciprocate by providing, as appropriate and feasible, re-mastered copies in digital formats so that the musicians could more easily access and, if desired, distribute these materials on their own. It is my hope, shared by those who participated in this project, that the collection will provide in perpetuity a history of a moment in time when an unusually large number of talented Ethiopian musician gained asylum in the United States and became part of the larger fabric of American life.

In retrospect, I can identify three main areas of this project in which reciprocity emerged as both an opportunity and as a challenge. The first involved ethics surrounding processes of documentation and preservation. The materials that archives house do serve to preserve, but they can also canonize certain practices, and, under certain circumstances, raise a degree of risk. I tried to avoid obvious pitfalls by including musicians from the widest array of musical genres, and actively sought interviewees from across the full spectrum of Ethiopian/African Horn ethnic/national backgrounds, generations, and genders. While I hope that its inclusiveness will defeat efforts at canonization, it is possible that some materials in the collection (such as details of individual human rights activity that a number of interviewees insisted be included) might prove embarrassing or even dangerous if circulated in the politically charged Ethiopian diaspora or homeland. Throughout the project, I also had concerns that my initial contacts and invitations to participate in the project, circulated both personally and through various community internet 
networks, might have unwittingly caused distress (and self exclusion) among musicians who did not have legal residency status.

A second issue revolves around the complex challenges of reciprocity on the individual level. While some would separate compensation- something material given to another- from reciprocity, which is seen as sharing of things that are comparable (Pekkala 2007, 177-78), I have found that distinction quite difficult to maintain in this project. Most of the musicians with whom I worked struggled economically; they worked as taxi drivers, hotel clerks, and healthcare workers, performing at night in area restaurants or traveling on weekends to appear in newly founded Ethiopian communities all over the United States and Canada. These individuals gave generously of their limited time in conversations with me about their music and its role in their lives; they invited me to their homes and to their performances; and they often gave me copies of CDs they published, refusing reimbursement.

Offering material compensation to individuals is an option little discussed in the ethnomusicological literature except in passing and it is not mentioned in SEM ethical guidelines. Giving gifts has long been an important act in Ethiopian society, at once closely linked to principles of both prestige and obligation; gifting has continued valence in Ethiopian diaspora social life. Sitting for an interview was surely considered to be, in part, a gift by the individual to this researcher. It also took time away from work or family for the individual and sometimes resulted in direct expenses for transport or even a babysitter. My direct offers of reimbursement for expenses incurred were more often than not refused as a matter of pride.

After a great deal of thought, I decided to give individuals participating in the project gift certificates for local Ethiopian restaurants as a practical yet symbolic gesture of thanks. The gifting was done by mail after the interview to forestall any embarrassment as well as perceptions of a reward for certain types of intellectual material. Thus gift certificates in this instance project a graceful way to satisfy cultural and economic considerations. 
A third concern was how to extend reciprocity more broadly and to be of help to the musical community at large. I was able to use my knowledge and contacts to recommend musicians for performance opportunities that were remunerated, both at universities and through local presenting networks. Helping to identify grants available to individuals through state arts councils was another option, as was nominating accomplished individual musicians for honors, ranging from citations presented by local municipalities in which the musicians dwelled to recommendations for state or national honorary fellowships. Many musicians aspire to more education; in this context, I was able to help individuals prepare their CVs and to aid them in locating appropriate institutions as they worked to establish new professional lives. But these reciprocal efforts were admittedly uneven in their outcomes since some musicians were better positioned by virtue of their musical repertories, educational backgrounds, and other qualities for an ethnomusicologist to be able to help them in substantive ways. For instance, most available 'folk arts' fellowship privilege traditional musical repertories and their official transmitters in diaspora, and make no provisions for the many talented musicians who cross boundaries and seek to innovate. There are also finite limits to an individual scholar's own time and resources, even when they exceed those of the individuals with which one is working.

What expectations are raised by reciprocity? What should expectations be for sharing royalties or even grants obtained to carry out the research? These questions are important ones that defy simple answers, although financial reciprocity ideally needs to be balanced with broader efforts that will benefit both individuals and the communities of which they are a part.

My activities described here are a recent iteration of my search for opportunities for reciprocity with people with whom I work; all are contingent and must be subject to constant reevaluation. Each researcher must chose his or her own path with sensitivity to shared ethical considerations in musical scholarship as well as to the people with whom they are engaged. While the current trend toward social activism among scholars is surely vital to an ethical scholarship, at some moments, a best practice can constitute what one does not do, a moment when scholarly 
intervention can generate a truly negative outcome. ${ }^{\mathrm{xx}} \mathrm{I}$ have also found that the highly charged political environment of the Ethiopian and Eritrean diasporas, not to mention the factionalized world of homeland ethnic politics, raise constant questions of what an appropriate intervention might in fact constitute.

There is no "end" to ethnography or to the human relationships established as part of that process. One must behave ethically if one is to live with the outcomes of one's own work, not to mention the colleagues who are either helped by one's success in the moral domain or held hostage by one's ethical failures as they come along afterwards. What is sure, as Anthony Appiah has so cogently noted, is that "figuring out moral principles, as an idle glance at the history of moral philosophy will show you, is hard ... One reason that life is full of hard decisions is that it's not easy to identify single principles ... that aim to tell you what to do ... Another reason is that it is often unclear what the effects will be of what we do ... On the other hand, many decisions aren't so hard, because some of our firmest moral knowledge is about particular cases" (Appiah 1996, 162).

In an essay on "Thinking as Moral Act," Clifford Geertz wrote that one of his more disturbing realizations after thinking long and hard about a particular problem was that his thoughts were much more effective in exposing the problems than in uncovering solutions to them (Geertz 2000, 24). I share this sentiment, believing it is one to which we should all aspire: to expose the problem and, in so doing, open pathways for new ethical solutions.

\section{Bibliography}

American Anthropological Society, 'Code of Ethics of the American Anthropological Association', approved June 1998, Appendix A, in C. Fluehr-Lobban (ed.), Ethics and the Profession of Anthropology, Walnut Creek, CA: AltaMira Press, 2003, pp. 247-54 
American Musicological Society, 'Guidelines for Ethical Conduct', American Musicological Society, http://www.ams-net.org/ethics.html

Appiah, K.A. Cosmopolitanism: Ethics in a World of Strangers, New York: W.W. Norton, 2006

Araújo, S., and members of The Grupo Musicultura/ Universidade Federal e Rio de Janeiro, 'Conflict and Violence as Theoretical Tools in Present-Day Ethnomusicology: Notes on a Dialogic Ethnography of Sound Practices in Rio de Janeiro', Ethnomusicology, 50, 2 (2006), 286-313

Atkinson, C. 'From the President', American Musicological Society, http://www.amsnet.org/from_the_president

Averill, G. A Day for the Hunter, A Day for the Prey: Popular Music and Power in Haiti, Chicago: University of Chicago Press, 1997

Babiracki, C. 'What's the Difference? Reflections on Gender and Research in Village India', in G.F. Barz and T.J. Cooley (eds.), Shadows in the Field: New Perspectives for Fieldwork in Ethnomusicology, $2^{\text {nd }}$ edn., New York: Oxford University Press, 2008, pp. 167-82

Barz, G.F., and T.J. Cooley (eds.), Shadows in the Field: New Perspectives for Fieldwork in Ethnomusicology, $1^{\text {st }}$ edn., New York: Oxford University Press, 1997; $2^{\text {nd rev. }}$ edn., 2008

Barz G.F., and J.M. Cohen (eds.), The Culture of AIDS in Africa. Hope and Healing Through Music and the Arts, Oxford and New York: Oxford University Press, 2011

Bayoumi, M. 'Disco Inferno', The Nation, 26 December 2005, htto://www.thenation.com/doc/20051226/bayoumi

Berreman, G.D. 'Ethics versus “Realism” in Anthropology: Redux', in C. Fluehr-Lobban (ed.), Ethics and the Profession of Anthropology, $2^{\text {nd }}$ edn., Walnut Creek, Calif.: Altamira Press, 2003, 51-83

Bishop, C. 'The Social Turn: Collaboration and Its Discontents', Artforum, 44, 6 (2006), 178-83 Blacking, J. 'The Music of Politics', in idem, Music, Culture, and Experience, ed. by R. Byron, Chicago: University of Chicago Press, 1995, 198-222 
Bohlman, P.V. 'On Cosmopolitanism: Our Journeys with Others.' SEM Newsletter, 40, 2 (2006), 4-5.

'Musicology as a Political Act', Journal of Musicology, 11, 4, (1993), 411-436

Bourgois, P. 'Foreword: Anthropology in the Global State of Emergency', in V. Sanford and A. Angel-Ajani, Engaged Observer: Anthropology, Advocacy, and Activism, New Brunswick, N.J.: Rutgers University Press, 2006, ix-xii

Bourriaud, N. 'Relational Aesthetics/1998', in C. Bishop (ed.), Participation, Documents of Contemporary Art, Cambridge, Mass.: MIT Press, 2006, 160-71

Census Bureau, United States Census, 2000, http://www.census.gov/main/www/cen2000.html

Cheng, W. 'Role-Playing toward a Virtual Musical Democracy in The Lord of the Rings Online', Ethnomusicology 56, 1 (2012), 31-62

Conquerwood, Dwight. 'Performing as a Moral Act. Ethical Dimensions of the Ethnography of Performance', Literature in Performance 5, 2 (1985), 1-13.

'Cultural Agents: Building Society Through Arts and Humanities', Harvard University. http://culturalagents.org/

Cusick, S. 'Music as Torture, Music as Weapon', Revista Transcultural de Música/Transcultural Music Review, 10 (2006), http://www.sibetrans.com/trans/trans10/cusick_eng.htm

'Ethics', in C. Soanes and A. Stevenson (eds.), The Concise Oxford English Dictionary Online, $11^{\text {th }}$ edn., New York: Oxford, 2007

Fesmire, S. John Dewey: Moral Imagination, Pragmatism in Ethics, Bloomington: Indiana University Press, 2003

Fieser, J. The Internet Encyclopedia of Philosophy Ethics. Dictionary MSN Encarta, http://encarta.msn.com/dictionary_1861609283/ethics.html

Fjell, T.I. 'Research in the Minefield of Privacy and Intimacy: The Problems of Consent', in S. Apo, H. Bausinger, et al. (eds.), Research Ethics in Studies of Cultural and Social Life: 
FF Communications, Edited for the Folklore Fellows, vol. 140, 292, Helsinki:

Suomalainen Tiedeakatemia and Academia Scientiarum Fennica, 2007, pp. 96-113

Fluehr-Lobban, C. (ed.), Ethics and the Profession of Anthropology, $2^{\text {nd }}$ edn., Walnut Creek, Calif.: Altamira Press, 2003

Geertz, C. Available Light: Anthropological Reflections on Philosophical Topics, Princeton: Princeton University Press, 2000

Georges, R.A., People Studying People: The Human Element in Fieldwork, Berkeley: University of California Press, 1980

Gowans, C. 'Moral Relativism', Stanford Encyclopedia of Philosophy. http://plato.stanford.edu/entries/moral-relativism/

Haidt, J., and C. Joseph, 'Intuitive ethics: How innately prepared intuitions generate culturally variable virtues', Daedelus, Fall 2004, 55-66

Klein, B. 'Folklore Archives, Heritage Politics and Ethical Dilemmas', in S. Apo, H. Bausinger, et al. (eds.), Research Ethics in Studies of Culture and Social Life: FF Communications, Edited for the Folklore Fellows, vol. 140, 292, Helsinki: Suomalainen Tiedeakatemia and Academia Scientiarum Fennica, 2007, 114-36

Koen, B. (ed.) The Oxford Handbook of Medical Ethnomusicology, New York: Oxford University Press, 2008

Lassiter, L.E. The Chicago Guide to Collaborative Ethnography, Chicago: University of Chicago Press, 2005

Lysloff R.T.A., and L.C. Gay, Music and Technoculture, Middletown: Wesleyan University Press, 2003

Malm, W.P. Personal communication. 31 December 2007

McAllester, David. 'A Problem in Ethics', in J. Kassler and J. Stubington (eds.), Problems \& Solutions: Occasional Essays in Musicology presented to Alice M. Moyle, Sydney: Hale \& Iremonger, 1984, 279-89. 
Meskell, L., and P. Pels, 'Introduction: Embedding Ethics', in L. Meskel and P. Pels (eds.), Embedding Ethics, Oxford: Berg, 2005,1-26

Miller, Kiri, Playing Along: Digital Games, YouTube, and Virtual Performance, Oxford: Oxford University Press, 2012.

Nettl, B. The Study of Ethnomusicology: Twenty-Nine Issues and Concepts, $1^{\text {st }}$ edn., Urbana: University of Illinois Press, 1983

Nussbaum, M.C. 'Introduction', in M.C. Nussbaum and J. Glover (eds.), Women, Culture and Development: A Study of Human Capabilities, Oxford: Clarendon Press, 1995, 1-34

O'Connell, J.M., and S. El-Shawan Castelo-Branco, Music and Conflict, Urbana: University of Illinois Press, 2010

Pekkala, A. 'Persuasion or Coercion? Striving for Understanding in Conducting Open Interviews', in A. Satu, H. Bausinger, et al. (eds.), Research Ethics in Studies of Culture and Social Life. FF Communications. Edited for the Folklore Fellows, vol. 140, 292, Helsinki: Suomalainen Tiedeakatemia and Academia Scientiarum Fennica, 2007, 167-91 Popular Music Section, Society for Ethnomusicology, 'The Music and Fair Use Forum of the Popular Music Section of the SEM', March 2005

Putnam, H. 'Pragmatism and Moral Objectivity', in M. Nussbaum and J. Glover (eds.), Women, Culture and Development: A Study of Human Capabilities, Oxford: Clarendon Press, $1995,199-224$

Reigersberg, Muriel E. Swijghuisen, 'Research Ethics, Positive and Negative Impact, and Working in an Indigenous Australian Context, Ethnomusicology Forum, 20, 2 (2011), $255-62$

Sanford, V. 'Introduction', in V. Sanford and A. Angel-Ajani (eds.), Engaged Observer: Anthropology, Advocacy, and Activism, New Brunswick, N.J.: Rutgers University Press, $2006,1-15$ 
Scruggs, T.M. 'Música y el legado de la violencia a finales del siglo XX en Centro América', Trans-Revista Transcultural de Música/Transcultural Music Review, 10 (2006), http://www.sibetrans.com/trans/trans10/indice10.htm

Personal communication, 5 January 2008

Seeger, A. 'Lost Lineages and Neglected Peers: Ethnomusicologists Outside Academia', Ethnomusicology, 50, 2 (2006),214-35

Shelemay, K.K. 'A New System of Musical Notation in Ethiopia', in S. Segert and A.T.E. Bodrogligeti (eds.), Ethiopian Studies Dedicated to Wolf Leslau, Wiesbaden: Otto Harrassowitz, 1983, pp. 571-92

'Together in the Field: Team Research among Syrian Jews in Brooklyn, New York', Ethnomusicology 32, 3 (1988), 369-84

A Song of Longing: An Ethiopian Journey, Urbana: University of Illinois Press, 1991a

'Recording Technology, the Record Industry, and Ethnomusicological Scholarship', in B. Nettl and P.V. Bohlman (eds.), Comparative Musicology and Anthropology of Music: Essays on the History of Ethnomusicology, Chicago: University of Chicago Press, 1991b, 277-92

'The Impact and Ethics of Musical Scholarship', in N. Cook and M. Everist (eds.), Rethinking Music, New York: Oxford University Press, 1999, pp. 531-44

'Ethiopian Musical Invention in Diaspora: A Tale of Three Musicians', Diaspora 15, 2/3 (2006) published 2011, 303-20

Shelemay, K.K. and S. Kaplan, 'Introduction', in K.K. Shelemay and S. Kaplan (eds.), Diaspora, Special Issue: Creating the Ethiopian Diaspora: Perspectives Across the Disciplines, 15, 2/3, 2006 (published 2011), 191-214

Slobin, M. 'Ethical Issues', in H. Myers (ed.), Ethnomusicology: An Introduction, New York: W.W. Norton, 1992, 329-36 
Society for American Music, "Guidelines for Ethical Conduct," The Society for American Music, http://american-music.org/organization/ethics.php

'Resolutions Introduced at the SAM Business Meeting, 3 March 2007', Society for American Music, http://american-music.org/organization/tick_resolution.php

Society for Ethnomusicology, 'Statement on Ethical Considerations', Society for Ethnomusicology, http://www.ethnomusicology.org/?EthicsStatement

'Position Statement on Torture', 2 February 2007

Society for Music Theory, [Bylaws on political activity], http://societymusictheory.org/administration/legal

Solis, T. (ed.) Performing Ethnomusicology: Teaching and Representation in World Music Ensembles, Berkeley: University of California Press, 2004

Sommer, D. (ed.) Cultural Agency in the Americas, Durham, N.C.: Duke University Press, 2006

Stokes, M., 'Ethnomusicology' (part 4), in S. Sadie (ed.), The New Grove Dictionary of Music and Musicians, $2^{\text {nd }}$ edn., London: Macmillan, 2001, 386-95

Titon, J.T. (ed.) 'Introduction: Music, the Public Interest, and the Practice of Ethnomusicology', Ethnomusicology 36, 3 (1992), 315-22

Turino, T. Nationalists, Cosmopolitans, and Popular Music in Zimbabwe, Chicago: University of Chicago Press, 2000

Welchman, J. Dewey's Ethical Thought, Ithaca: Cornell University Press, 1995

\section{Notes}

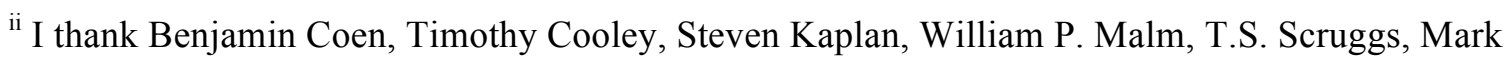
Slobin, Doris Sommer, and Judith Tick, for advice and comments on aspects of this paper. Responses from colleagues present at seminar discussions of this paper at the University of
} 
California, Berkeley, and the University of Toronto, were also invaluable. I am grateful to the Radcliffe Institute for Advanced Studies, the John Simon Guggenheim Memorial Foundation, and the National Endowment for the Humanities for fellowships that gave me release time from teaching to write this essay.

iii Philip Bohlman's "Becoming Ethnomuscologists" column in the SEM Newsletter discussed the connection of ethics with cosmopolitanism (2006:4-5).

${ }^{\text {iv }}$ See Fieser, J. The Internet Encyclopedia of Philosophy Ethics. Dictionary MSN Encarta. http://encarta.msn.com/dictionary 1861609283/ethics.html; see also Fesmire 2003, 4, who adds a fourth category, descriptive ethics, which subsumes "neutral descriptions of moral thinking and behavior."

${ }^{\mathrm{v}}$ For details of the long history of ethical issues and edicts in anthropology, see Berreman 2003. ${ }^{v i}$ This is a paraphrase of the title of one of the early sources on human relations - and ethical and unethical behavior in the field - by Georges 1980 .

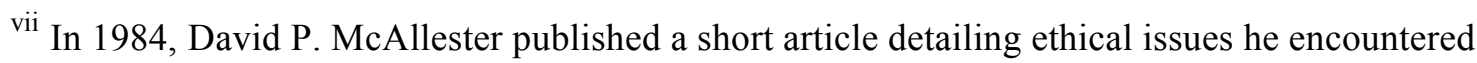
when making a film of a Navajo Blessingway ceremony, one of the first such discussions in the literature. I thank Benjamin Brinner for bringing this article to my attention.

viii Barz and Cooley 1997; see essays by Babiracki, Beaudry, Noll, Shelemay, and Titon. The second edition of this volume contains passing discussion of ethics in the introduction and reprinted and revised chapters, as well as more commentary on ethics in new essays by Berger, Cohen, Kippen, Seeger, and Stock and Chou (Barz and Cooley 2007). ${ }^{\text {ix }}$ See Society for American Music, 'Guidelines for Ethical Conduct'). The Society for Music Theory does not have ethical guidelines posted, but does have a statement in their 2007 Bylaws that prohibits any sort of organized political activity (Society for Music Theory 2007). The SMT website also contains a section on "Other Policies and Guidelines" that contains documents regarding accessibility, sustainability, language, and mentoring. 
${ }^{\mathrm{x}}$ See Dwight Conquergood 1985 for an early discussion of the ethical dimensions of the ethnography of performance.

${ }^{x i}$ Ethical concerns in virtual fields has generated a large literature of its own; see Lysloff and Gay 2003, Cheng 2012, and Miller 2012.

xii The position paper on Fair Use was prepared by 'The Music and Fair Use Forum of the Popular Music Section of the SEM', dated March 2005. The 'Position Statement on Torture' was posted on 2 February 2007. 'Position Statement on Ethnographic Research and Institutional Review Board' is dated January 16, 2008.

xiii Cusick 2006 brought these issues to a broad audience of music scholars (see also http://www.sibetrans.com/trans/trans10/cusick_eng.htm). An emerging literature on this subject is found in the general press as well; see, for example, Bayoumi 2005.

${ }^{\text {xiv }}$ SEM added a similar statement to the SEM website on October 4, 2007.

${ }^{x v}$ See Scruggs 2006. I thank T.M. Scruggs for providing an English translation of this article (Scruggs 2008).

${ }^{x v i}$ See also O’Connell and El-Shawan Castelo-Branco 2010.

${ }^{\text {xvii }}$ In a few cases, I have been able to work in the United States with the same individuals I had contact with in Ethiopia. For instance, Tesfaye Lemma, who was the director of Orchestra Ethiopia when I did participant-observation with that ensemble during 1974-1975, remains a close research associate and friend in the United States (see Shelemay 1983, 571-92 and Shelemay 2011). For additional background on the Ethiopian diaspora, see Shelemay and Kaplan 2011.

xviii According to the 2000 U.S. Census, Ethiopians are surpassed only by the number of Nigerian immigrants (Census Bureau, United States Census 2000) (http://www.census.gov/main/www/cen2000.html) 
${ }^{\text {xix }}$ I am grateful to the John. W. Kluge Center at the Library of Congress and to Librarian of Congress James H. Billington for a residency as the Chair for Modern Culture that made it possible for me to spend the summers of 2007 and 2008 in Washington, D.C., initiating this project.

${ }^{\mathrm{xx}}$ See Shelemay 1999 for a discussion of an ethical conundrum in which I had to refrain from political action on behalf of the community because my scholarly findings had the potential to damage their political aspirations. A recent discussion of related issues can be found in Reigersberg 2011. 